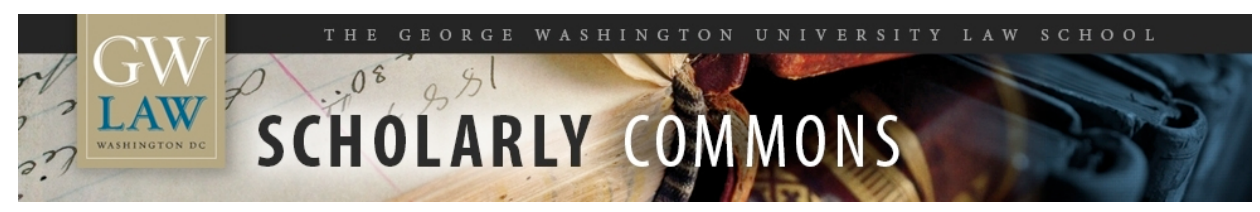

\title{
Federal Rule of Evidence 408 and Criminal Cases
}

Stephen A. Saltzburg

George Washington University Law School, ssaltz@law.gwu.edu

Follow this and additional works at: https://scholarship.law.gwu.edu/faculty_publications

Part of the Law Commons

\section{Recommended Citation}

Research Paper Series, GWU Law, Federal Rule of Evidence 408 and Criminal Cases (2011). 26 Crim. Just. (2011) ; GWU Law School Public Law Research Paper No. 2011-2; GWU Legal Studies Research Paper No. 2011-2. Available at SSRN: http://ssrn.com/abstract=2669956

This Article is brought to you for free and open access by the Faculty Scholarship at Scholarly Commons. It has been accepted for inclusion in GW Law Faculty Publications \& Other Works by an authorized administrator of Scholarly Commons. For more information, please contact spagel@law.gwu.edu. 


\section{Federal Rule of Evidence 408 and Criminal Cases} BY STEPHEN A. SALTZBURG

$\mathrm{H}$ ow does Fed. R. Evid. 408 operate in a criminal case? This is a question that few lawyers have had occasion to ask in their careers and even fewer have had occasion to answer. There are two principal reasons: First, because Rule 408 deals with offers to compromise civil disputes while Fed. R. Evid. 410 is the rule that focuses on plea bargaining and compromising criminal cases; and second, prior to an amendment of Rule 408 a number of federal courts held that it simply had no applicability in criminal prosecutions. Although the cases disagreed on the applicability of Rule 408 in criminal cases, there were so few cases involving the rule that it simply was ignored by most lawyers and judges handling criminal cases. Once Rule 408 was amended in 2006, it became clear on the face of the rule that it reached criminal prosecutions, and it also became clear that, even though it may not be invoked frequently in criminal cases, prosecutors, defense counsel, and judges have to understand how it works.

\section{An Illustrative Case}

United States v. Davis, 596 F.3d 852 (D.C. Cir. 2010), illustrates in part the kind of protection that Rule 408 can afford a criminal defendant who seeks to exclude evidence of an offer to settle what appeared to be a civil dispute. An earlier article discussed the case in connection with the intersection of personal knowledge, hearsay, and best evidence objections, but a brief description of the facts is in order to set the stage for the discussion of the Rule 408 issue.

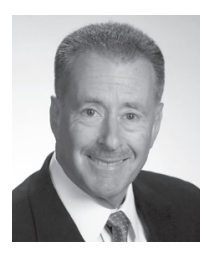

STEPHEN A. SALTZBURG, a pastchair of the Criminal Justice Section, is the Wallace and Beverley Woodbury University Professor at George Washington University School of Law in Washington, D.C., and contributing editor to Criminal Justice magazine. He is also author of the book, Trial Tactics, Second Edition (2009, American Bar Association), an updated and expanded compilation of his columns.
Terry Davis had been the national treasurer of the Phi Beta Sigma fraternity. He was charged with 10 counts of bank fraud, one count of firstdegree theft, and one count of first-degree fraud. A jury acquitted him on two bank fraud counts and convicted him on all the other counts.

The fraternity, founded at Howard University in 1914, has university and alumni chapters with more than 120,000 members who pay annual dues that are deposited in a general fund bank account and used to pay the fraternity's operating expenses. Davis was an elected, unpaid officer of the fraternity. He disregarded the fraternity's policy with respect to authorization of vouchers to pay expenses and signatures on checks. He wrote checks without obtaining approved vouchers, and sometimes failed to obtain the cosignature required on the checks.

When the fraternity investigated financial irregularities and discovered what Davis had done, it suspended him and installed a new treasurer, Jimmy Hammock, who found at least $\$ 29,000$ in checks that had been made out to cash that was not deposited in the fraternity's bank account. These checks gave rise to the prosecution.

\section{The Rule 408 Issue}

Hammock testified as follows: He asked Davis to produce the financial records Davis maintained on the fraternity's behalf. Davis provided some unused checks and financial reports but no cancelled checks or bank statements. He also asked Davis why he had written fraternity checks payable to cash, and Davis explained that he transferred the funds to the fraternity's payroll account.

Davis filed a motion in limine seeking to bar Hammock from testifying about his second conversation with Hammock. The defense motion quoted the following portion of an FBI report of an interview with Hammock:

Sometime between the National Conclave and August 2003, HAMMOCK had a telephone conversation with DAVIS, during which he confronted DAVIS about the checks made payable to cash and DAVIS' explanation [that] the money was deposited to the payroll account. DAVIS said the money had been deposited into the payroll account, but HAMMOCK replied "TERRY, I'm telling you, I've gone through the records and it didn't." DAVIS then unexpectedly said "what will it take to make this go away?" HAMMOCK 
responded that DAVIS needed to repay "whatever you took." DAVIS asked "what if Isplit the $\$ 29,000$ ?" HAMMOCK told DAVIS the amount of missing money was in excess of $\$ 100,000.00$, to which DAVIS responded, "Oh, I can't pay that much."

Davis's motion relied upon Fed. R. Evid. 408:

(a) Prohibited uses.-Evidence of the following is not admissible on behalf of any party, when offered to prove liability for, invalidity of, or amount of a claim that was disputed as to validity or amount, or to impeach through a prior inconsistent statement or contradiction:

(1) furnishing or offering or promising to furnish - or accepting or offering or promising to accept - a valuable consideration in compromising or attempting to compromise the claim; and (2) conduct or statements made in compromise negotiations regarding the claim, except when offered in a criminal case and the negotiations related to a claim by a public office or agency in the exercise of regulatory, investigative, or enforcement authority.

(b) Permitted uses.-This rule does not require exclusion if the evidence is offered for purposes not prohibited by subdivision (a). Examples of permissible purposes include proving a witness's bias or prejudice; negating a contention of undue delay; and proving an effort to obstruct a criminal investigation or prosecution.

The trial judge rejected the motion, and Hammock testified about a second conversation with Davis regarding these checks. Hammock said that told he Davis the fraternity had found $\$ 29,000$ in checks made out to cash, none of which was deposited in the fraternity's bank account, and that Davis asked "Can we just split this \$29,000.00 and make this situation just go away?" According to Hammock, he told Davis "[the] amount was in excess of a hundred thousand dollars," Davis said, "I can't afford to pay that amount," and Hammock finished the conversation by telling Davis that "Terry, if you want to do some-negotiate some kind of settlement, you need to talk to our legal counsel or our international president."

Were Davis's Statements Offers to Settle? Davis claimed that his statements amounted to an offer to settle a claim that was disputed as to validity. The trial judge rejected the argument, but the court of appeals agreed with Davis as it said the following:

There can be no doubt that Davis offered to compromise a disputed claim. His offer was to split the $\$ 29,000$ in checks to cash he thought the fraternity had discovered. . . . Davis did not confess to taking the fraternity's money; he said that he had deposited the cash checks into the fraternity's payroll account; and Hammock rejected Davis's explanation. . . . It is also clear that the government intended to introduce Davis's settlement offer in order to prove Davis's guilt, or in the words of Rule 408(a), his "liability."” (506 F.3d at 859.)

The court reasoned that "[t]he Rule is meant to promote settlements. . . If one party attempts to initiate negotiations with a settlement offer, the offer is excluded from evidence even if the counterparty responds: 'I'm not negotiating with you.' It makes no sense to force the party who initiates negotiations to do so at his peril." (Id.) Since there was no doubt that Davis attempted to settle the claim that Hammock made on behalf of the fraternity, Davis was within the coverage of Rule 408 even if Hammock told him he would have to negotiate with someone else.

\section{Did Davis Offer a Valuable Consideration?}

It is clear from Hammock's testimony that Davis offered to pay one-half of the $\$ 29,000$ that was the subjects of discussion between the two men. No one could dispute that $\$ 14,500$ has value. Nevertheless, the government argued that Davis did not offer "valuable consideration" because Davis's offer of $\$ 14,500$ fell short of the $\$ 29,000$ Hammock said Davis owed. Thus, the government's argument was that the consideration did not qualify under Rule 408. The court of appeals made short shrift of this argument by reasoning "[u]nder that theory, only a settlement offer exceeding the full amount of the disputed claim is an offer of valuable consideration," and "[t] he framers of Rule 408 could not have intended any such thing." (Id.)

The court of appeals' reasoning is sound. The government's argument would essentially render Rule 408 a nullity because anyone who offered less than the other side claimed it was entitled to 
would not get the protection of Rule 408. This would make settlement discussions risky rather than safe as the drafters intended.

\section{Was the Government's Evidence Admissible for Another Purpose?}

The government also argued that Davis's statements were admissible not to prove "liability" but for another purpose. The court of appeals explained the argument and rejected it as follows:

There is, as the government points out, a sentence in the 1972 advisory committee note to Rule 408 stating that an "effort to 'buy off' the prosecution or a prosecuting witness in a criminal case is not within the policy of the rule of exclusion." FED. R. EVID. 408 advisory committee's note (1972 proposed rule). But it would be a mistake to read much into that remark, particularly in cases in which the defendant's actions give rise to potential civil and criminal liability. The 2006 amendment to Rule 408, which made clear that the rule applied to both civil and criminal proceedings, drew a distinction between civil disputes involving the government and civil disputes involving private parties. Under amended Rule 408, a defendant's statements in settlement negotiations with government agencies may be admitted in a criminal case. FED. R. EVID. 408(a)(2). But if the civil dispute was with a private party, the defendant's offer of settlement and statements in negotiation may not be admitted in a criminal prosecution when "offered to prove liability for, invalidity of, or amount of a claim." FED. R. EVID. 408(a).

(Id. at 860.)

The court concluded that the government was trying to prove Davis's guilt or "liability" through his statements and did not seek to offer the statements for a limited purpose. Thus, the exclusionary rule of Rule 408 applied:

This still leaves the example in Rule 408(b) allowing the use of a defendant's settlement offer and statements in negotiation in order to prove the defendant's attempt to obstruct a criminal investigation. This example, and the statement in the 1972 advisory notes, are easy enough to understand when obstruction is one of the criminal charges.... But even in such cases there may be difficulties. One problem is that settlement evidence, like other evidence, may be introduced for multiple purposes, some prohibited under Rule 408(a), some permitted under Rule 408(b). . . . Another problem is whether the "obstruction" illustration applies only to pending criminal investigations or also to potential investigations. In Davis's case, for instance, there was no date identifying the beginning of a criminal investigation and there was no evidence indicating that Davis knew of any criminal investigation when he talked to Hammock. There may be other difficulties in some cases. One might suppose that if - as in this case - the same acts give rise to potential civil and criminal liability, any settlement of the civil dispute could forestall or influence potential criminal proceedings. Yet to hold that offers of settlement and negotiations in that context amount to obstruction would be contrary to the purpose of Rule 408 ... and would contradict the notes of the advisory committee in 2006.

Davis was not charged with obstructing a criminal investigation or attempting to do so. We can say with some assurance that when he offered to split the difference on $\$ 29,000$, he was not trying to bribe Hammock. All indications are that Davis was proposing to pay the money to the fraternity. It may be that an offer of settlement, excessive in amount, could be seen as an attempt to "buy off" a complaining party. But Davis's offer obviously was not of that sort, which is why Hammock rejected it out of hand.

The most important consideration is that the government did not introduce the Hammock-Davis conversation for the purpose of "proving an effort to obstruct a criminal investigation." FED. R. EVID. 408(b). When asked at oral argument whether this was the government's purpose, counsel for the government candidly admitted it was not. She explained, as the prosecutor had argued to the jury, that the conversation revealed Davis's consciousness of guilt. But that is one of the prohibited purposes in Rule 408(a). Consciousness of guilt proves "liability" for a disputed claim under Rule 408(a).

(Id. at 860-61.) 
The 2006 Advisory Committee Note to which the court referred stated that if settlement offers and negotiations between private parties were admissible, this would be contrary to the policy of Rule 408 to avoid chilling such negotiations. Thus, the court concluded not only that the government had not offered the Rule 408 evidence to prove an effort to obstruct a criminal investigation, but also that there was no evidence in the case that Davis was aware of any criminal investigation or took any action that could fairly be said to be an attempt to obstruct any such investigation.

\section{The Conclusion}

The court held that the trial judge abused discretion in admitting Davis's settlement discussions. Because both parties had mentioned those discussions in closing argument, the court found it difficult to determine whether or not the evidence was prejudicial to Davis. The court therefore vacated Davis's convictions and remanded the case to the trial judge for consideration in the first instance of whether the error in admitting the settlement evidence required reversal of the convictions.

\section{Lessons}

1. It is now clear that Rule 408 applies in criminal cases as well as in civil cases. The ambiguity that preceded the 2006 amendment to Rule 408 has been removed.

2. Parties who desire to exclude evidence under Rule 408 are required to register timely objections or make motions in limine as Davis did in this case.
3. An offer to settle qualifies under Rule 408 if there is a disputed claim as to validity or amount and a party makes a genuine offer to settle that claim even though the other party does not want to negotiate.

4. An offer to settle a dispute involving money involves valuable consideration even though the offer is less than the other party believes it is entitled to.

5. There is a difference under Rule 408 when a party bargains about a claim with the government and when it bargains with private parties. The rule puts potential criminal defendants on notice that statements made to government agencies may be used against them in criminal cases notwithstanding that the statements were made in the course of attempting to settle civil claims.

6. A party desiring to offer settlement discussions for a purpose other than to prove liability (or guilt) must make clear an intent to offer the evidence for a limited purpose. The government failed to do so in Davis's case.

7. A party desiring to offer settlement discussions to prove something like an attempt to obstruct a criminal investigation bears the burden of showing that there was such an attempt. In cases like Davis, where there was no criminal investigation pending and no evidence that Davis was contemplating a criminal investigation or prosecution, meeting that burden might be difficult or even impossible. 